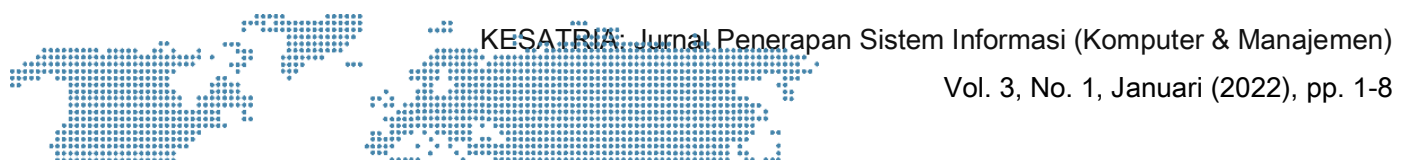

\title{
Analisis Data Mining Pesebaran Siswa Smp Di Pematangsiantar "... Dengan Metode Algoritma K-Means Clustering
}

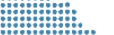

${ }^{1}$ Kurnia ssandi Purba, ${ }^{2}$ Dedy Härtama, ${ }^{3}$ Suhada

${ }^{1,2}$ STHKoM Tunas Bämgsa, Pematang

${ }^{3}$ AMIKK Tunas Bangsa, Pematangsiantar, Sumatera Utara, Indonesia

${ }^{1}$ sandipurba40@gmail.com, ${ }^{2}$ dedyhartama@amiktunasbangsa.ac.id,

${ }^{3}$ suhada.atb@gmail.com

\begin{abstract}
Abstrak
Data Mining adalah analisis otomatis dari data yang berjumlah besar atau kompleks dengan tujuan untuk menemukan pola atau kecenderungan yang penting yang biasanya tidak disadari keberadaannya Data siswa SMP Pematang Siantar saat ini sudah terkumpul cukup banyak. Namun data siswa tersebut belum dimanfaatkan secara maksimal sehingga menyulitkan pihak sekolah dalam melakukan perkembangan siswa di sekolah. Masing-masing siswa akan melakukan perbandingan antara pelayanan yang diinginkan dengan pelayanan yang di terima. Algoritma K-Means merupakan algoritma teknik cluster yang berulang-ulang. Algoritma ini dimulai dengan pemilihan secara acak, yang merupakan banyaknya cluster yangi ingin dibentukAtribut yang dibutuhkan dalam pengolahan adalah kota asal siswa, asal sekolah siswa, dan nilai siswa. Berdasarkan atribut tersebut selanjutnya data akan dikelompokan menjadi siswa SMP berdasarkan asal kota, asal sekolah, dan nilai siswa menggunakan algoritma K-Means ClusteringH asil dari pengelolahan data tersebut akan sangat membantu pihak sekolah SMP, Sehingga diketahui pesebaran setiap siswa SMP terbanyak. Dalam penelitian ini data yang digunakan adalah data siswa SMP angkatan 2018-2019 yang terdapat di Pematangsiantar sebanyak 300 sampel data
\end{abstract}

Kata Kunci : Persebaran Wilayah, Clustering, K-Means, Data Mining

\begin{abstract}
Data Mining is an automatic analysis of large or complex data with the aim of finding important patterns or trends that are usually not realized. However, the student data has not been utilized optimally, making it difficult for the school to carry out student development at school. Each student will make a comparison between the desired service with the service received. The K-Means algorithm is an iterative cluster technique algorithm. This algorithm starts with random selection, which is the number of clusters that you want to form. The attributes needed in processing are the student's hometown, the student's school origin, and the student's grade. Based on these attributes, the data will then be grouped into junior high school students based on city origin, school origin, and student grades using the K-Means Clustering algorithm. The results of processing this data will greatly help the junior high school, so that it is known that the distribution of each junior high school student is the most. In this study, the data used were data from junior high school students from the 2018-2019 class in Pematangsiantar as many as 300 data samples.
\end{abstract}

Keywords : Regional Distribution, Clustering, K-Means, Data Mining

\section{Pendahuluan}

Kemajuan teknologi informasi sudah semakin berkembang pesat disegala bidang pemprosesan data. Banyak sekali data yang dihasilkan oleh teknologi informasi yang canggih, mulai dari bidang industri, ekonomi, teknologi serta di bidang 


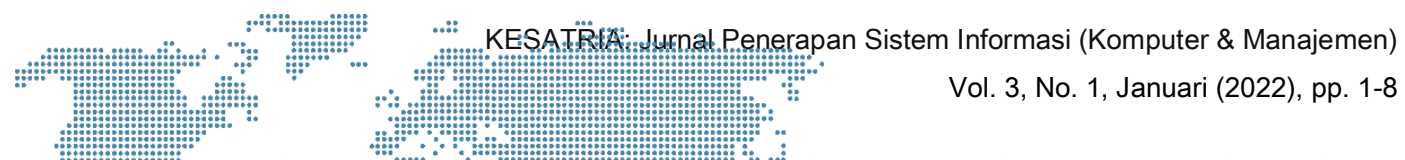

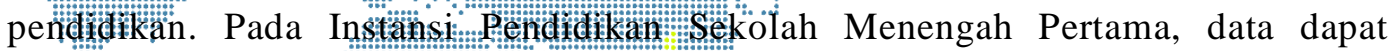

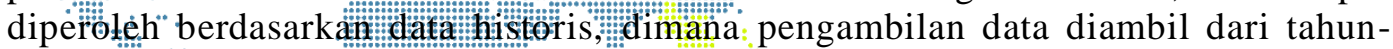

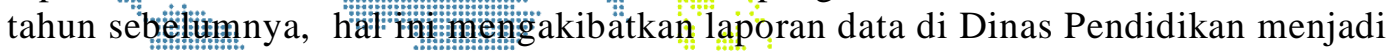
tidak akurat Ylakk disini penulis ingin meng Cluster pesebaran siswa SMP yang ada

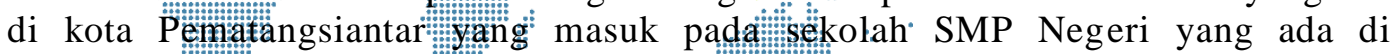
Pematangsulantar yang berasal di setiap Kéeanuatan di Pematangsiantar yang mana

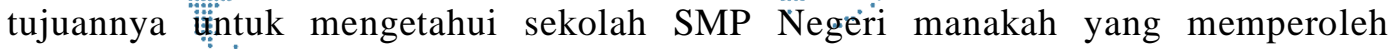
pesebaran tertinggi dan terendah berdasarkan Kecamatan yang ada di kota Pematangsiantar.

Dengan Algoritma K-Means Clustering diharapkan akan diketahui berapa banyak siswa di setiap sekolah SMP yang terdaftar pada dinas pendidikan, serta membantu setiap sekolah dalam memantau perkembangan siswa di sekolah. Atribut yang dibutuhkan dalam proses pengelompok adalah jumlah sekolah negeri, jumlah sekolah swasta, jumlah siswa negeri, jumlah siswa swasta berdasarkan kecamatan yang ada di Pematangsiantar. atribut tersebut selanjutnya data akan dikelompokan dengan metode $K$-Means.

Adapun dalam penyelesaian penelitian ini berlandaskan pada penelitian ini berlandaskan pada penelitian terdahulu seperti penelitan oleh [1] tentang : Implementasi Algoritma K-Means untuk Clustering Penyebaran Tuberkulosis di Kabupaten Karawang menyatakan bahwa Algoritma K-Means dapat diaplikasikan dalam Clustering penyebaran Tuberculosis di Kabupaten Karawang dengan nilai evaluasi $S S E$ yaitu 2,4402 yang merupakan gabungan dari jumlah Cluster $\mathrm{K}=3$ dengan random seed $\mathrm{S}=10$, hasil evalusai dari Silhouette sebesar 0,5629 dan diperoleh Cluster 0 terdiri dari (7 kecamatan), Cluster 1 (9 kecamatan), dan Cluster 2 (14 kecamatan). Dan penelitian oleh [2] tentang : Analisis Sebaran Titik Rawan Bencana dengan K-Means Clustering dalam Penanganan Bencana bahwa Algoritma $K$-Means dapat digunakan dalam analisis sebaran titik rawan bencana dalam penanganan bencana dengan hasil Cluster 0 yaitu 200 titik daerah, Cluster 1 yaitu 48 titik daerah dan Cluster 2 yaitu 26 titik daerah dan dalam atribut sebanyak 4 yaitu Longtitude, Latitude, Jenis Bencana dan Dampak Bencana.

Dari penjabaran latar belakang diatas, penulis menerapak data mining dalam analisis pesebaran siswa smp di pematangsiantar dengan metode algoritma $k$-means Clustering. Penelitian ini diharapkan dapat membantu pihak Dinas Pendidikan Pematangsiantar dalam mengelompokkan data persebaran wilayah siswa smp di kota pematangsiantar agar dapat mempercepat proses dari segi promosi dan tingkat pelayanan yang baik dalam menentukan hasil meningkatnya jumlah siswa yang ada pada di sekolah SMP Pematangsiantar. Penelitian ini juga diharapkan dapat menjadi referensi bagi peneliti selanjutnya yang berkaitan dengan pengguna Algoritma yang digunakan.

\section{Metodologi Penelitian}

\subsection{Data Mining}

Menurut Nasution (2014) Data Mining adalah proses yang menggunakan teknik statistik, matematika, kecerdasan buatan, dan Machine Learning untuk mengektrasi dan mengidentifikasi informasi yang bermanfaat dan pengetahuan yang terkait dari berbagai database besar. Data Mining dapat juga didefenisikan sebagai gabungan dari suatu pengalaman, nilai, informasi kontekstual dan juga pandangan pakar yang memberikan suatu framework untuk mengevaluasi dan menciptakan pengalaman baru dan informasi [3]. Data Mining adalah bagian dari tahapan proses KDD. Data Mining atau Knowledge Discovery in Database (KDD) adalah penyaringan data secara implisit dimana sebelumnya tidak diketahui terdapatnya informasi yang potensial [4]. 

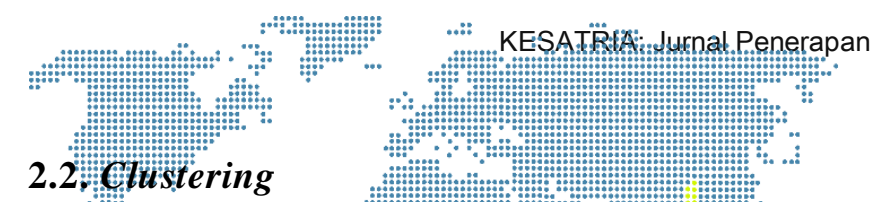

Sistem Informasi (Komputer \& Manajemen)

Vol. 3, No. 1, Januari (2022), pp. 1-8

\subsection{Atustering}

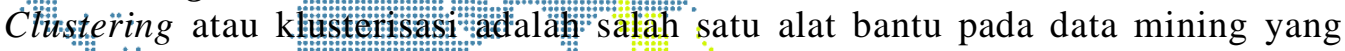
bertujuan kMengelompok ka objek-objek ke dalam cluster - cluster." [5]. "Potensi Clustering adalath dapat dogmakan untuk mengetăhui struktur dalam data yang dapat

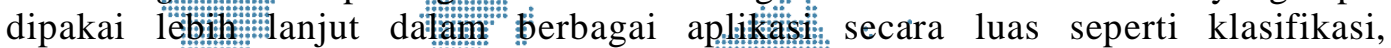
pengolahan untuk menimimalkan terjadinya objective function yang diset dalam proses Clustering, yang pada umumnya digunakan untuk meminimalisasikan variasi dalam suatu cluster dan memaksimalkan variasi antar cluster [7].

\subsection{Algoritma K-Means}

K-Means adalah suatu metode penganalisaan data atau metode Data Mining yang melakukan proses pemodelan tanpa supervisi (unsupervised) dan merupakan salah satu metode yang melakukan pengelompokan data dengan sistem partisi [4]. Tujuan dari $K$-Means adalah pengelompokkan data dengan memaksimalkan kemiripan data dalam satu klaster dan meminimalkan kemiripan data antar klaster [8]. Berikut adalah Alur penyelesaian dari metode K-Means[9]:

a) Tentukan berapa jumlah klaster yang ingin ditetapkan pusat cluster $\mathrm{k}$.

b) Menggunakan jarak euclidean dan kemudian menghitung setiap data ke pusat cluster.

$$
d_{i k} \sqrt{\sum_{j}^{m}\left(C_{i j}-C_{k j}\right)}
$$

c) Kategorikan data ke dalam cluster dengan jarak yang terpendek dengan menggunakan persamaan

$$
\operatorname{Min} \sum_{k}^{k}=d_{i k}=d_{i k} \sqrt{\sum_{j}^{m}\left(C_{i j}-C_{k j}\right)}
$$

d) Menghitung pusat cluster dengan menggunakan persamaan

$$
C_{k j} \frac{\sum_{i=1}^{p} X_{i j}}{p}
$$

Dengan : xij $€$ Kluster ke $-\mathrm{k}$ p = banyak member kluster ke $-\mathrm{k}$

5. Silahkan ulangi langkah dua sampai empat sehingga sudah tidak ada lagi data yang berpindah ke kluster yang lain.

\section{Hasil dan Pembahasan}

Analisis data yang digunakan penelitian ini menggunakan data kuantitatif dengan teknik analisis data yang menggunakan jenis statistik deskriptif. Penelitian dilakukan di Dinas Pendidikan Pematangsiantar. Data yang telah dikumpulkan untuk diolah atau ditransformasikan ke format data Ms. Excel 2010. Data yang ditransformasikan tersebut digunakan sebagai syarat dalam pengolahan Data Mining dengan Teknik Clustering menggunakan Algoritma K-Means.

Tabel 1. Data Persebaran Wilayah SMP Pematangsiantar

\begin{tabular}{|c|l|l|l|c|}
\hline No & \multicolumn{1}{|c|}{ Nama } & Asal Kecamatan & \multicolumn{1}{c|}{ Asal Sekolah } & Nilai Akhir \\
\hline 1 & Amalia Wahyu Nugrahen & Siantar Barat & SMP Negeri 1 Kota Pematang Siantar & 85 \\
\hline 2 & Dea Hasanah & Siantar Barat & SMP Negeri 2 Kota Pematang Siantar & 90 \\
\hline 3 & Ike Oktaviani & Siantar Barat & SMP Negeri 3 Kota Pematang Siantar & 70 \\
\hline 4 & Rahmat Andri Setiawan & Siantar Barat & SMP Negeri 4 Kota Pematang Siantar & 75 \\
\hline 5 & Ainun Sholihah & Siantar Barat & SMP Negeri 5 Kota Pematang Siantar & 70 \\
\hline 6 & Maya Puspitasari & Siantar Sitalasari & SMP Negeri 6 Kota Pematang Siantar & 85 \\
\hline 7 & Sugito & Siantar Sitalasari & SMP Negeri 7 Kota Pematang Siantar & 70 \\
\hline 8 & Nabila & Siantar Sitalasari & SMP Negeri 8 Kota Pematang Siantar & 70 \\
\hline 9 & Febri Dwi nadila & Siantar Sitalasari & SMP Negeri 9 Kota Pematang Siantar & 85 \\
\hline 10. & Eko Sutrisno & Siantar Marimbun & SMP Negeri 10 Kota Pematang Siantar & 70 \\
\hline 11. & Zuhan Nahdiyah & Siantar Marimbun & SMP Negeri 11 Kota Pematang Siantar & 85 \\
\hline 12. & Siti asmah & Siantar Marimbun & SMP Negeri 12 Kota Pematang Siantar & 90 \\
\hline
\end{tabular}




\begin{tabular}{|c|c|c|c|c|}
\hline \multicolumn{5}{|c|}{ 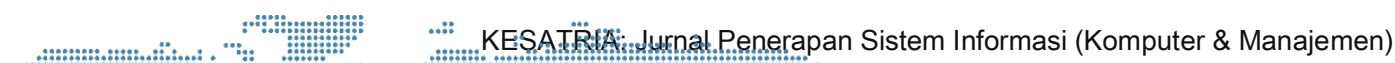 } \\
\hline No & W" & Asal Kecamatan & Asal Sekolah & Nilai Akhir \\
\hline 13. & Dianpurnama sari & Stantari Martoba & SMP Negeri 1 Kota Pematang Siantar & 70 \\
\hline 14 & Attica:puspita & Sirantar-Martởba & SMP Negeri 2 Kota Pematang Siantar & 75 \\
\hline 15 & Feni: & Sfratioar Selatan & SMP Negeri 3Kota Pematang Siantar & 70 \\
\hline 16 & 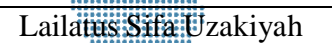 & Siantar Selatan & SMP Negeri 4 Kota Pematang Siantar & 85 \\
\hline 17 & 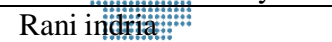 & Sivaintair Utara & 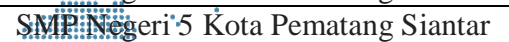 & 85 \\
\hline 18 & Adhenia Iitri & Stantar Utara & SIM $\quad$ eri 6 Kota Pematang Siantar & 85 \\
\hline 19 & Nur fitriliestari & Siantar Barat & SMP Negeri 7 Kota Pematang Siantar & 70 \\
\hline 20 & Muhammad Rofi'uddin A & Siantar Barat & SMP Negeri 8 Kota Pematang Siantar & \\
\hline 21 & Fatimah angelica sundari & Siantar Barat & SMP Negeri 9 Kota Pematang Siantar & 85 \\
\hline$\ldots$ & $\ldots$ & ... & $\ldots$ & $\ldots$ \\
\hline 300 & Dwi lisyanti & Siantar Timur & SMP Negeri 11 Kota Pematang Siantar & 70 \\
\hline
\end{tabular}

Langkah-langkah penyelesaian menggunakan algoritma $K$-Medoids antara lain sebagai berikut:

a) Menentukan Data yang diolah, Data yang digunakan adalah data persebaran siswa SMP di Kota Pematangsiantar yang sudah di rekapitulasi menjadi perkecamatan. Berikut data yang digunakan untuk pengolahan Algoritma KMeans:

Tabel 2. Data Persebaran Siswa SMP tahun 2016

\begin{tabular}{|c|l|c|c|c|c|}
\hline No & Kecamatan & $\begin{array}{c}\text { Jumlah Sekolah } \\
\text { Negeri }\end{array}$ & $\begin{array}{c}\text { Jumlah Sekolah } \\
\text { Swasta }\end{array}$ & $\begin{array}{c}\text { Jumlah Siswa } \\
\text { Negeri }\end{array}$ & $\begin{array}{c}\text { Jumlah Siswa } \\
\text { Swasta }\end{array}$ \\
\hline 1 & Siantar Marihat & 0 & 2 & 0 & 504 \\
\hline 2 & Siantar Selatan & 3 & 5 & 172 & 101 \\
\hline 3 & Siantar Barat & 1 & 13 & 2968 & 1887 \\
\hline 4 & Siantar Utara & 2 & 3 & 1237 & 2845 \\
\hline 5 & Siantar Timur & 2 & 7 & 1505 & 672 \\
\hline 6 & Siantar Martoba & 3 & 5 & 2136 & 1476 \\
\hline 7 & Siantar Marimbun & 1 & 2 & 786 & 145 \\
\hline 8 & Siantar Sitalasi & 3 & 0 & 2072 & 0 \\
\hline \multicolumn{2}{|l}{ Jumlah } & 15 & 37 & 10876 & 7630 \\
\hline
\end{tabular}

b) Menentukan Jumlah Cluster

Jumlah Cluster atau k yang digunakan sebanyak 2 yaitu Cluster Tinggi dan Cluster Rendah.

c) Menentukan Pusat Medoid

Menentukan Pusat Medoid dilakukan secara acak pada masing-masing Cluster. Pusat Medoid yang digunakan adalah :

Pusat Medoid awal Tinggi $=(2,3,1237,2845)$

Pusat Medoid awal Rendah $=(0,2,0,504)$

d) Menghitung Nilai Euclidian

Untuk menghitung jarak antara titik Medoid dengan titik tiap objek menggunakan Euclidian Distance:

$$
\begin{aligned}
\mathrm{D}_{x l, c l} & =\sqrt{(0-2)^{2}+(2-3)^{2}+(0-1237)^{2}+(504-2845)^{2}} \\
& =2647,726 \\
\mathrm{D}_{x 2, c l} & =\sqrt{(3-2)^{2}+(5-3)^{2}+(172-1237)^{2}+(101-2845)^{2}} \\
& =2943,428 \\
\mathrm{D}_{x 3, c 1} & =\sqrt{(1-2)^{2}+(13-3)^{2}+(2968-1237)^{2}+(1887-2845)^{2}} \\
& =1978,44 \\
\mathrm{D}_{x 4, c l} & =\sqrt{(2-2)^{2}+(3-3)^{2}+(1237-1237)^{2}+(2845-2845)^{2}} \\
& =0 \\
\mathrm{D}_{x 5, c l} & =\sqrt{(2-2)^{2}+(7-3)^{2}+(1505-1237)^{2}+(672-2845)^{2}} \\
& =2189,468 \\
\mathrm{D}_{x 6, c l} & =\sqrt{(3-2)^{2}+(5-3)^{2}+(2136-1237)^{2}+(1476-2845)^{2}} \\
& =1637,793 \\
&
\end{aligned}
$$




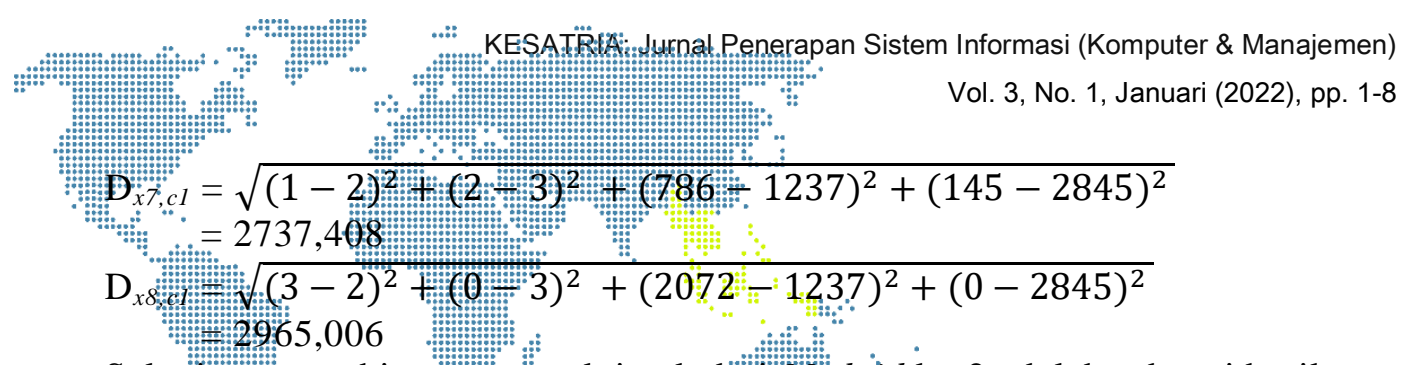

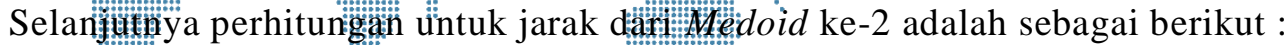

$$
\begin{aligned}
& \mathrm{D}_{x 1, c 2} \text { 霸 } \sqrt{(0-0)^{2}+(2-2)^{2}+(0-0)^{2}+(504-504)^{2}} \\
& \stackrel{\stackrel{\circ}{=} 0}{ } 0 \\
& \mathrm{D}_{x 2, c 2}=\sqrt{(3-0)^{2}+(5-2)^{2}+(172-0)^{2}+(101-504)^{2}} \\
& =438,1906 \\
& \mathrm{D}_{x 3, c 2}=\sqrt{(1-0)^{2}+(13-2)^{2}+(2968-0)^{2}+(1887-504)^{2}} \\
& =3274,421 \\
& \mathrm{D}_{x 4, c 2}=\sqrt{(2-0)^{2}+(3-2)^{2}+(1237-0)^{2}+(2845-504)^{2}} \\
& =2647,726 \\
& \mathrm{D}_{x 5, c 2}=\sqrt{(2-0)^{2}+(7-2)^{2}+(1505-0)^{2}+(672-504)^{2}} \\
& =1514,357 \\
& \mathrm{D}_{x 6, c 2}=\sqrt{(3-0)^{2}+(5-2)^{2}+(2136-0)^{2}+(1476-504)^{2}} \\
& =2346,763 \\
& \mathrm{D}_{x 7, c 2}=\sqrt{(1-0)^{2}+(2-2)^{2}+(786-0)^{2}+(145-504)^{2}} \\
& =864,1053 \\
& \mathrm{D}_{x 8, c 2}=\sqrt{(3-0)^{2}+(0-2)^{2}+(2072-0)^{2}+(0-504)^{2}} \\
& =2132,42
\end{aligned}
$$

Sehingga didapat tabel jarak dari Medoid dan mencari nilai minimal dari ketiga Medoid. Tabel Jarak dari Medoid adalah sebagai berikut:

Tabel 3. Hasil Jarak Medoid Iterasi

\begin{tabular}{|l|c|c|c|}
\hline \multicolumn{1}{|c|}{ Kecamatan } & C1 & C2 & Jarak Terpendek \\
\hline Siantar Marihat & 2647,726 & 0 & 0 \\
\hline Siantar Selatan & 2943,428 & 438,1906 & 438,1906 \\
\hline Siantar Barat & 1978,44 & 3274,421 & 1978,44 \\
\hline Siantar Utara & 0 & 2647,726 & 0 \\
\hline Siantar Timur & 2189,468 & 1514,357 & 1514,357 \\
\hline Siantar Martoba & 1637,793 & 2346,763 & 1637,793 \\
\hline Siantar Marimbun & 2737,408 & 864,1053 & 864,1053 \\
\hline Siantar Sitalasi & 2965,006 & 2132,42 & 2132,42 \\
\hline
\end{tabular}

Dari tabel 4 dapat dilihat hasil jarak Medoid iterasi 1 yang akan digunakan untuk menentukan nilai Cost. Nilai Jarak Dekat ini yang akan digunakan sebagai letak cluster atau kelompok berdasarkan nilai terkecil perbaris.

e) Lakukan Ulang Langkah 4 dan 5 dengan nilai Pusat Medoid baru

Untuk mendapatkan Pusat Medoid baru, diperoleh dari penjumlahan cluster untuk bagian Cluster 1 dan Cluster 2. Mengulangi proses meghitungan nilai jarak dekat Medoid dengan nilai pusat Medoid baru secara acak, yaitu :

Pusat Medoid baru Tinggi $=(2,7,2113,667,2069,333)$

Pusat Medoid baru Rendah $=(1,8,3,2,907,284,4)$.

Dari pengolahan menggunakan pusat Medoid baru diperoleh hasil sebagai Tabel 4 berikut :

Tabel 4. Hasil Jarak Medoid Iterasi 2

\begin{tabular}{lccc}
\hline \multicolumn{1}{c}{ Kecamatan } & C1 & C2 & Jarak Terpendek \\
\hline Siantar Marihat & 2630,187 & 933,2084 & 933,2084 \\
Siantar Selatan & 2764,853 & 757,5389 & 757,5389 \\
Siantar Barat & 873,5948 & 2610,775 & 873,5948 \\
Siantar Utara & 1170,564 & 2581,777 & 1170,564
\end{tabular}




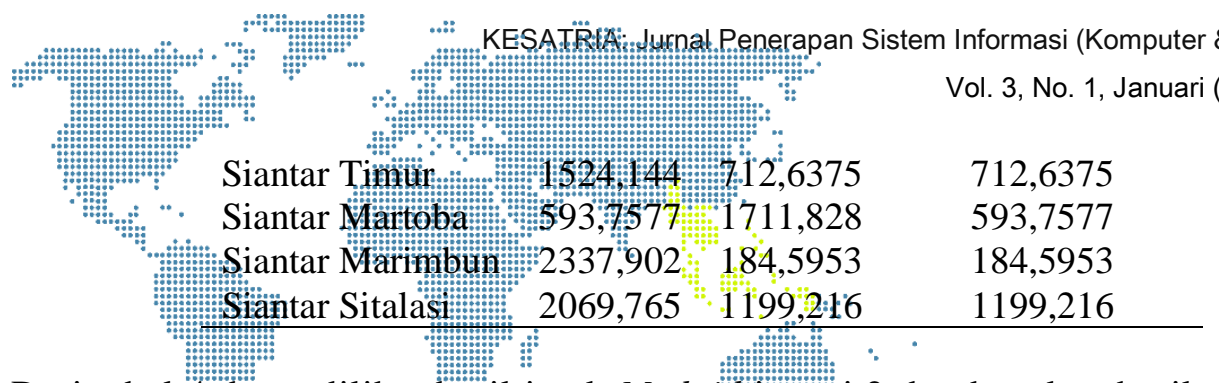

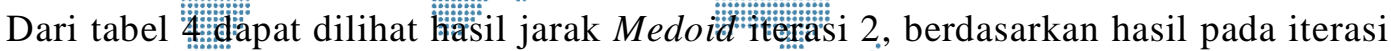
kedua. Diperoleh hasil cluster atau pengelompokkan yang sama, artinya proses pengelompokkan berhenti.

f) Mencari Cluster atau Pengelompokkan

Untuk menentukan Cluster diperoleh dengan menentukan nilai Cluster 1 dan 2 terdekat dengan Nilai Jarak Distance sehingga diperoleh Cluster persebaran siwa SMP di Kota Pematangsiantar adalah sebagai berikut :

Tabel 5. Cluster Tahun 2018

\begin{tabular}{|l|c|c|}
\hline Kecamatan & C1 & C2 \\
\hline Siantar Marihat & - & 1 \\
\hline Siantar Selatan & - & 1 \\
\hline Siantar Barat & 1 & - \\
\hline Siantar Utara & 1 & - \\
\hline Siantar Timur & - & 1 \\
\hline Siantar Martoba & 1 & - \\
\hline Siantar Marimbun & - & 1 \\
\hline Siantar Sitalasi & - & 1 \\
\hline
\end{tabular}

Dari tabel 5 dapat dilihat hasil cluster yang diperoleh dari iterasi terakhir persebaran siswa SMP di Kota Pematangsiantar. Diperoleh Cluster Tinggi terdapat pada Kecamatan Siantar Barat, Siantar Utara dan Siantar Martoba. Untuk Cluster Rendah terdapat pada Kecamatan Siantar Marihat, Siantar Selatan, Siantar Timur, Siantar Marimbun dan Siantar Sitalasari.

Setelah melakukan pengolahan data secara manual, selanjutnya dilakukan pengujian data menggunakan tools rapidminer dengan cara membuat model Algoritma K-Means di tools RapidMiner. Dari hasil pemodelan data menggunakan tools rapidminer, maka diperoleh hasil pengelompokkan persebaran siswa SMP di Kota Pematangsiantar yang dapat dilihat pada gambar 1 berikut :

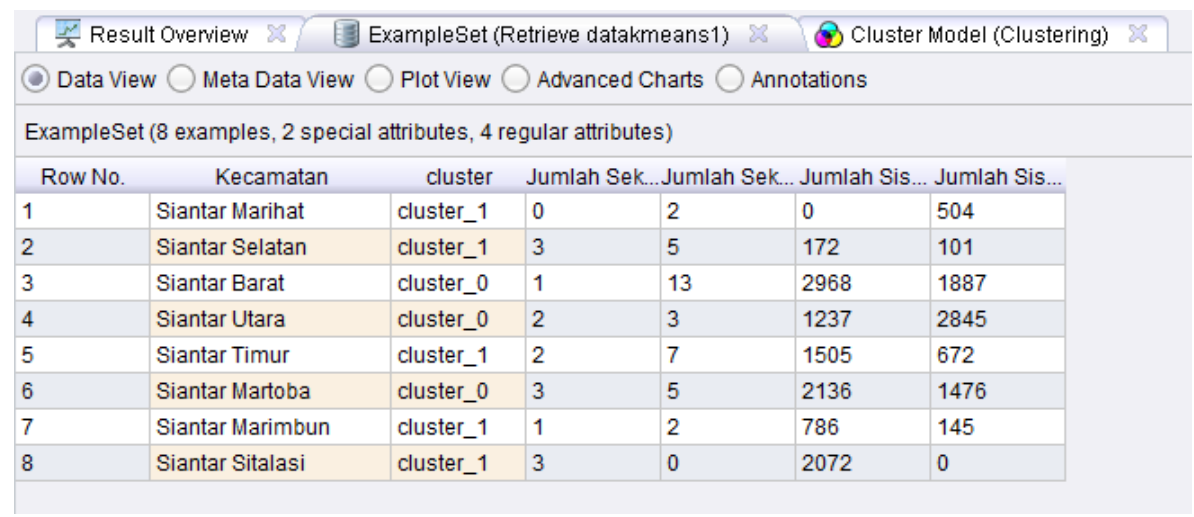

Gambar 1. Hasil Cluster Algoritma K-Means

Dari gambar 1 dapat dilihat bahwa hasil pengelompokkan berdasarkan kecamatan yang terdiri dari Cluster Tertinggi (Cluster 0) yaitu Kecamatan Siantar Barat, Siantar Utara dan Siantar Martoba. Cluster Rendah yaitu Kecamatan Siantar Marihat, Siantar Selatan, Siantar Timur, Siantar Marimbun dan Siantar Sitalasari. 


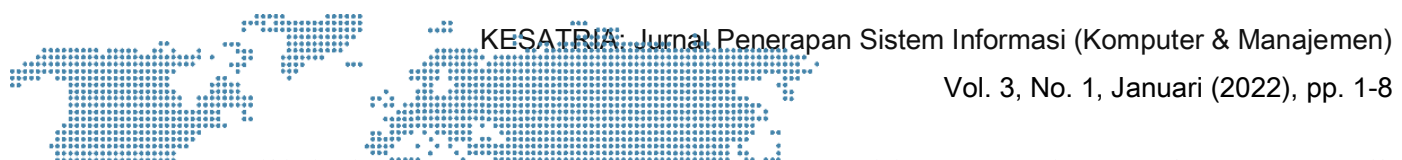

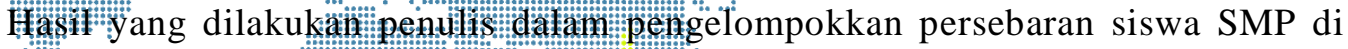
Kotä:Pëmatangsiantar adalah of cister Tinggi diperoleh Kecamatan Siantar Barat,

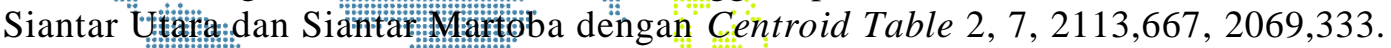
Sedangkân êtuster Rendaht điperoleh Kecamatan: Siantar Marihat, Siantar Selatan,

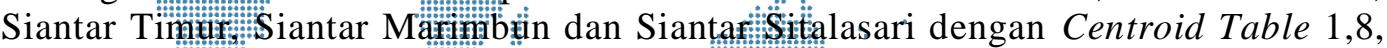

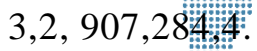

Hasil yang diberikan oleh tools RapidMiner dałam pengelompokkan persebaran siswa SMP di Kota Pematangsiantar adalah Cluster Tinggi diperoleh Kecamatan Siantar Barat, Siantar Utara dan Siantar Martoba dengan Centroid Table 2, 7, 2113,667, 2069,333. Sedangkan Cluster Rendah diperoleh Kecamatan Siantar Marihat, Siantar Selatan, Siantar Timur, Siantar Marimbun dan Siantar Sitalasari dengan Centroid Table 1,8, 3,2, 907,284,4. Berdasarkan pernyataan hasil antara perhitungan yang dilakukan penulis dengan hasil yang diperoleh tools RapidMiner memiliki kesamaan hasil pengelompokkan persebaran siswa SMP di Kota Pematangsiantar. Karena hal tersebut hasil dari penelitian ini adalah valid dan dapat dijadikan sebagai bahan referensi terkait pengelompokkan siswa SMP.

\section{Kesimpulan}

Kesimpulan yang didapat dari penulisan skripsi ini adalah:

a) Hasil yang dilakukan penulis dalam pengelompokkan persebaran siswa SMP di Kota Pematangsiantar adalah Cluster Tinggi diperoleh Kecamatan Siantar Barat, Siantar Utara dan Siantar Martoba dengan Centroid Table 2, 7, 2113,667, 2069,333. Sedangkan Cluster Rendah diperoleh Kecamatan Siantar Marihat, Siantar Selatan, Siantar Timur, Siantar Marimbun dan Siantar Sitalasari dengan Centroid Table 1,8, 3,2, 907,284,4.

b) Hasil antara perhitungan yang dilakukan penulis dengan hasil yang diperoleh tools RapidMiner memiliki kesamaan hasil pengelompokkan persebaran siswa SMP di Kota Pematangsiantar.

c) Hasil yang didapatkan oleh penulis dan tools RapidMiner adalah Cluster Tinggi diperoleh Kecamatan Siantar Barat, Siantar Utara dan Siantar Martoba dengan Centroid Table 2, 7, 2113,667, 2069,333. Sedangkan Cluster Rendah diperoleh Kecamatan Siantar Marihat, Siantar Selatan, Siantar Timur, Siantar Marimbun dan Siantar Sitalasari dengan Centroid Tabel 1,8, 3,2, 907,284,4. Dengan berdasarkan hasil yang diperoleh pihak Dinas Pendidikan Kota Pematangsiantar dapat memperoleh informasi baru berupa data persebaran dengan kategori Tinggi dan Rendah. Informasi yang dihasilkan dapat menjadi acuan untuk teknik promosi, peningkatan pelayanan dan fasilitas, serta memenuhi kebutuhan dari sekolah-sekolah SMP dalam mencakup ruang dan kelas.

\section{Daftar Pustaka}

[1] Y. P. Sari, A. Primajaya, And A. S. Y. Irawan, "Implementasi Algoritma K-Means Untuk Clustering Penyebaran Tuberkulosis Di Kabupaten Karawang," Inovtek Polbeng - Seri Inform., Vol. 5, No. 2, P. 229, 2020, Doi: 10.35314/Isi.V5i2.1457.

[2] T. I. Hermanto And Y. Muhyidin, "Analisis Sebaran Titik Rawan Bencana Dengan KMeans Clustering Dalam Penanganan Bencana," J-Sakti (Jurnal Sains Komput. Dan Inform., Vol. 5, Pp. 406-416, 2021, [Online]. Available: Http://Ejurnal.Tunasbangsa.Ac.Id/Index.Php/Jsakti/Article/View/332.

[3] N. Butarbutar, A. P. Windarto, D. Hartama, And Solikhun, "Komparasi Kinerja Algoritma Fuzzy C-Means Dan K-Means Dalam Pengelompokan Data Siswa Berdasarkan Prestasi Nilaiakademik Siswa," Jurasik (Jurnal Ris. Sist. Inf. Tek. Inform., Vol. 1, No. 2012, 2016.

[4] S. R. S. Iskandar, Pilipus Tarigan, "Penerapan Data Mining Dalam Surat Jalan Transportasi Mobil Angkutan Menggunakan Metode Cluestering," J. Pelita Inform., Vol. 17, No. 4, Pp. 460-464, 2018. 


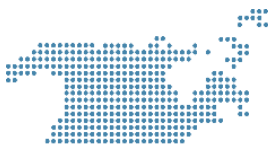

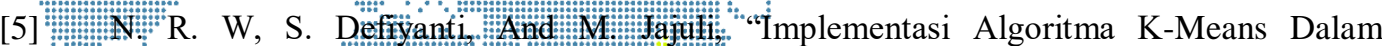

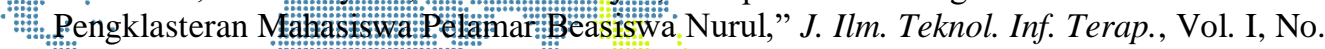

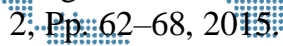

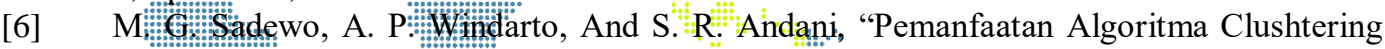

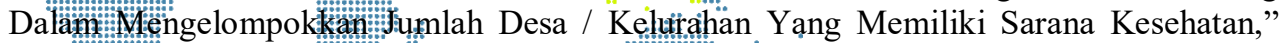
Vol.

[7] E. Mumingsih And S. "Kiswati, "Penerapan Metode.K-Means Untuk Clustering Produk Online: Shop Dalam Penentuan Stok Barang," Elly Muningsihl Dan Sri Kiswati2, Vol. 3, No. 1, 2015.

[8] B. R. C.T.I. Et Al., "Implemetasi K-Means Clustering Pada Rapidminer Untuk Analisis Daerah Rawan Kecelakaan,” Semin. Nas. Ris. Kuantitatif Terap. 2017, No. April, Pp. 5860, 2017.

[9] I. Parlina, A. P. Windarto, A. Wanto, And M. R. Lubis, "Memanfaatkan Algoritma KMeans Dalam Menentukan Pegawai Yang Layak Mengikuti Asessment Center Untuk Clustering Program Sdp,” Cess (Journal Comput. Eng. Syst. Sci., Vol. 3, No. 1, Pp. 87-93, 2018. 